\title{
Low prevalence of DNA viruses in the human endometrium and endometriosis
}

\author{
Anna L. Vestergaard • Ulla B. Knudsen · Torben Munk • Hanne Rosbach • \\ Seweryn Bialasiewicz $\cdot$ Theo P. Sloots · Pia M. Martensen · Annika Antonsson
}

Received: 9 October 2009/Accepted: 17 January 2010/Published online: 19 March 2010

(C) Springer-Verlag 2010

\begin{abstract}
The chronic female disease endometriosis causes debilitating pain and lowered fertility. The aetiology is unknown, but indications of an infectious agent are present. This study investigates the possible involvement of a pathogenic virus in endometriosis patients and controls. DNA was purified from biopsies and subjected to highly sensitive PCR tests detecting human papillomavirus (HPV) types, the herpes family viruses HSV-1 and $-2, \mathrm{CMV}$, and $\mathrm{EBV}$, and the polyomaviruses SV40, JCV, BKV, KIV, WUV, and MCV. The prevalence of pathogenic DNA viruses in the human endometrium was generally low $(0-10 \%)$. The virus prevalence was found to vary slightly when comparing the endometrium of healthy women and women with endometriosis. However, these were not significant differences, and no viruses were identified in endometriotic lesions. These results do not point towards any evidence that endometriosis is caused by these viruses.
\end{abstract}

A. L. Vestergaard · P. M. Martensen ( $₫)$

Department of Molecular Biology, Aarhus University,

C. F. Moellers Allé 3, 8000 Aarhus C, Denmark

e-mail: pmm@mb.au.dk

U. B. Knudsen - T. Munk · H. Rosbach

Gyncological-Obstetric Department,

Odense University Hospital, 5000 Odense C, Denmark

S. Bialasiewicz · T. P. Sloots

Clinical Medical Virology Centre,

Queensland Paediatric Infectious Diseases Laboratory, Royal Children's Hospital, The University of Queensland, Herston, QLD 4029, Australia

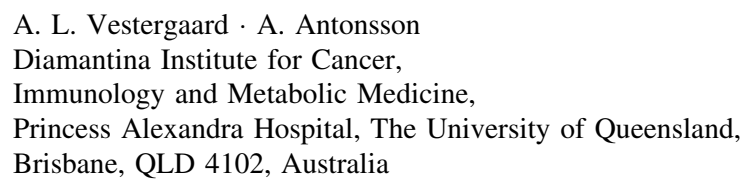

A. L. Vestergaard · A. Antonsson Diamantina Institute for Cancer, Immunology and Metabolic Medicine, Princess Alexandra Hospital, The University of Queensland, Brisbane, QLD 4102, Australia

\section{Introduction}

Endometriosis is defined as the presence of endometria-like tissue outside the uterus, and it predominantly targets the pelvic organs. The most common symptoms are pelvic pain and infertility. The incidence is estimated to be $6-10 \%$, and its pathogenesis is much debated. The endometrial tissue is believed to enter the pelvic cavity by retrograde menstruation, which occurs to some degree in most women [26]. However, it remains to be elucidated how the misplaced tissue develops into endometriotic lesions. Additional factors that increase susceptibility to endometriosis must exist, and in that respect, immunological factors on their own or together with viral infection might be involved.

Women with endometriosis have an increased risk for generalized diseases related to the immune system, e.g. rheumatoid arthritis [40, 41]. A broad spectrum of immunological factors are involved in endometriosis [41]. Focusing on the important immune-modulating cytokine family of interferons (IFNs), human recombinant IFN $\alpha-2 b$ has been shown to suppress the growth of cultured endometriosis cells in vitro in a dose-dependent manner [7], and clinical trials on intraperitoneal administration of IFN $\alpha-2 b$ following surgical removal of endometriotic lesions have yielded ambiguous results regarding reoccurrence of symptoms $[1,2]$.

Endometriosis has some features of malignancy, such as local invasive growth and distant implantation, and women with endometriosis have been found to be more prone for malignancies such as ovarian cancer and non-Hodgkin's lymphoma [32]. Cells from ectopic endometriotic lesions have been shown to display reduced apoptosis compared with the eutopic endometrium of both endometriosis patients and healthy women [9]. The implication of malignant transformation and effects of interferons as well 
as other immune modulators in endometriosis leads to the suggestion of a possible causal infectious agent.

During the last two decades, the large impact of a broad spectrum of pathogenic DNA viruses has become obvious, and a very significant example is the papillomaviruses. More than 118 papillomaviruses have been fully described, and new virus types are constantly emerging. Human papillomavirus (HPV, of the family Papillomaviridae) prevalence in cervical carcinomas is $99.7 \%$, and specific high-risk HPV types have been shown to cause the vast majority of cervical cancers as well as a substantial proportion of other anogenital cancers, head and neck cancers, and certain cutaneous cancers [18, 43, 47]. HPV has not yet been detected in intraperitoneal tissues, but HPV has been detected in blood, including on the surface of peripheral blood mononuclear cells, suggesting a potential alternative route of transmission [13].

Closely related to the papillomaviruses are the members of the family Polyomaviridae. The well-described human polyomaviruses JC (JCV), BK (BKV) and simian virus 40 (SV40) are widely distributed. Thus, antibodies against JCV and BKV have been found in more than $75 \%$ of the human adult population, and up to $15 \%$ of healthy humans are seropositive for SV40. These three small DNA viruses have been found in many different tissues, such as BKV in the kidney tubule epithelium, [20] the urethral epithelium, [36] the uterine cervix, and the spleen [36] JCV in tongue squamous cell epithelium, [30] urethral epithelium, [36] and the spleen [12] and SV40 in the liver and the mesothelium [15]. Furthermore, all three polyomaviruses induce tumors in animal models and malignantly transform cultured human cells [33]. In 2007, two new human polyomaviruses, WU polyomavirus (WUV) [25] and KI polyomavirus (KIV) [3] were discovered in respiratory tract secretions and have subsequently been detected in faeces, blood, and lymphoid tissue [34, 39]. The full spectrum of their tissue tropism and their role in disease has yet to be elucidated. More recently, yet another human member of the family Polyomaviridae, Merkel cell polyomavirus (MCV), was described in apparent association with Merkel cell carcinoma, an aggressive form of skin cancer [22]. All of these viruses are members of the genus Polyomavirus of the family Polyomaviridae.

Epstein-Barr virus (EBV, of the subfamily Gammaherpesvirinae, genus Lymphocryptovirus), cytomegalovirus (CMV, of the subfamily Betaherpesvirinae, genus Cytomegalovirus, species Human herpesvirus 5), and herpes simplex virus types 1 and 2 (HSV-1 and HSV-2, of the subfamily Alphaherpesvirinae, genus Simplexvirus, species Human herpesvirus 1 and Human herpesvirus 2) are all members of the family Herpesviridae and found in many human tissue types, such as the fallopian tubes (salpingitis) $[31,37]$ and the endometrium [37]. These viruses are commonly distributed as asymptomatic infectious agents, but they are also all associated with diseases, such as genital sores and various malignancies [11, 19, 46].

This study investigates the prevalence of a broad spectrum of pathogenic DNA viruses in women with endometriosis and healthy control women, using a series of specific polymerase chain reaction (PCR) assays.

\section{Materials and methods}

Subjects and samples

Clinical samples from 52 Danish women were studied. Tissue samples were collected at Odense University Hospital, Denmark, by three gynecologists (UBK, TM, and HR) and stored at $-80^{\circ} \mathrm{C}$ until utilized. Endometriosis samples (E) were obtained from 32 women who were surgically confirmed as having American fertility score (AFS) stage 1 (6/32), 2 (11/32), or 3 (13/32) endometriosis. The diagnoses were done by laparoscopies and verified histologically. Samples were taken from the eutopic endometrium from all 32 women suffering from endometriosis $(\mathrm{Eu})$, and ectopic endometriotic lesions $(\mathrm{Ec})$ were obtained from 27 of the same women by excision with scissor or biopsy forceps. The ectopic tissue came from either one of the ovaries or the peritoneum. Twenty women with no indication of endometriosis who requested sterilization agreed to participate in the study as healthy controls (C). Samples from the endometrium were taken by curettage (vabra aspirator) from both the controls and the women with endometriosis. Cervical smears were tested for the presence of HPV. The mean age $( \pm S D)$ of the participants was $31.72( \pm 6.29)$ years for the E group and 36.45 ( \pm 6.17 ) years for the $\mathrm{C}$ group. Collection of clinical material was approved by the local ethics committee, and all of the women gave written informed consent.

DNA was extracted from frozen 10-mg aliquots of endometrial or lesion tissue samples using DNeasy Blood and Tissue Kit (Qiagen, Hilden, Germany) according to the manufacturer's protocol. The resulting DNA concentrations were in the range of $9-180 \mathrm{ng} / \mu \mathrm{L}$ with a mean $( \pm \mathrm{SD})$ of $49.6( \pm 35.2) \mathrm{ng} / \mu \mathrm{L}$ as measured by OD260, and the purity was measured by OD $260 / 280$ ratio to be within the range of 1.6-2.5.

\section{PCR}

To confirm that no PCR-inhibiting agents were present in the DNA extracts, these were all subjected to PCR amplification of a fragment of the human L1 sequence, which is present in more than $10^{5}$ copies in human cells [18]. Twenty-five microliter PCR were mixed containing 
$5 \mu \mathrm{L}$ of template DNA, $1 \times$ ThermoPol Buffer with $1.5 \mathrm{mM} \mathrm{MgCl}{ }_{2}$ (NEB, Ipswich, MA, USA), $0.2 \mathrm{mM}$ of each deoxynucleotide (dNTP, Fisher Scientific, Suwanee, GA, USA), $0.8 \mu \mathrm{M}$ of each of the primers Human L1-F and
-R, respectively, and $1 \mathrm{U}$ Taq DNA polymerase (NEB). The sequences of all PCR primers and probes used are given in Table 1 . The PCR was initially denatured at $94^{\circ} \mathrm{C}$ for $4 \mathrm{~min}$, followed by 35 amplification cycles of $94^{\circ} \mathrm{C}$ for

Table 1 Primer and probe sequences used in PCR and real-time PCR assays

\begin{tabular}{|c|c|c|c|c|}
\hline Target & Oligonucleotide & Sequence $\left(5^{\prime}-3^{\prime}\right)$ & $\begin{array}{l}\text { Amplicon } \\
\text { size (bp) }\end{array}$ & Reference \\
\hline \multirow[t]{2}{*}{ Human L1 } & Human L1-F & TGTGGAAGTCAGTGTGGCGA & 294 & Deragon et al. [18] \\
\hline & Human L1-R & CCAATTTCATCCATGTCCCT & & \\
\hline \multirow[t]{4}{*}{ HPV } & FAP59 & TAACWGTIGGICAYVVWTATT & 478 & Forslund et al. [23] \\
\hline & FAP64 & CCWATATCWVHCATITCICCATC & & \\
\hline & GP5+ & TTTGTTACTGTGGTAGATACTAC & 150 & de Roda Husman et al. [16] \\
\hline & GP6+ & GAAAAATAAACTGTAAATCATATTC & & \\
\hline- & HSV-GF & GTGTTCGACTTTGCCAGCCTCTAC & - & Sahin et al. [38] \\
\hline HSV-1/2 & HSV-1-2R & GACTGGCTCGCCATGCGAAAGC & 223 & \\
\hline EBV & EBV-R & ACTCGTGCACGTGCTTCTTTAC & 176 & \\
\hline CMV & CMV-R & TTGACACTCGCGCATGCATTC & 242 & \\
\hline \multirow[t]{2}{*}{ Polyomavirus } & PM1+ & TCYTCTGGNNTAAARTCATGCTCC & - & Fedele et al. [21] \\
\hline & PM1- & AAWTAGRTKCCAACCTATGGAAC & & \\
\hline BKV & $\mathrm{BK}+$ & GAATGCTTTCTTCTATAGTATGGTATG & 353 & \\
\hline JCV & $\mathrm{JC}+$ & ATATTATGACCMCCAAAACCATG & 189 & \\
\hline SV40 & $\mathrm{SV}+$ & ATAATTTTTTTGTATAGTATAGTAGTGCA & 135 & \\
\hline- & PM2- & GGTAGAATACCCYAARGACTTTCC & - & \\
\hline \multirow[t]{6}{*}{ WUV } & WU-B-2729-F & CTACTGTAAATTGATCTATTGCAACTCCTA & 136 & Bialasiewicz et al. [10] \\
\hline & WU-B-2808-R & GGGCCTATAAACAGTGGTAAAACAACT & & \\
\hline & WU-B-2797-TM & FAM-ССТTTCCTCCACAAAGGTCAAGTAAA- BHQ1 & & \\
\hline & WU-C-4824-F & GGCACGGCGCCAACT & 115 & \\
\hline & WU-C-4898-R & CCTGTTGTAGGCCTTACTTACCTGTA & & \\
\hline & WU-C-4861-TM & FAM-TGCCATACCAACACAGCTGCTGAGC- BHQ1 & & \\
\hline \multirow[t]{6}{*}{ KIV } & KI-A-141-F & ACCTGATACCGGCGGAACT & 95 & Bialasiewicz et al. [10] \\
\hline & KI-A-200-R & CGCAGGAAGCTGGCTCAC & & \\
\hline & KI-A-182-TM & FAM-CCACACAATAGCTTTCACTCTTGGCGTGA-BHQ1 & & \\
\hline & KI-B-4603-F & GAATGCATTGGCATTCGTGA & 114 & \\
\hline & KI-B-4668-R & GCTGCAATAAGTTTAGATTAGTTGGTGC & & \\
\hline & KI-B-4632-TM & FAM-TGTAGCCATGAATGCATACATCCCACTGC- BHQ1 & & \\
\hline \multirow[t]{7}{*}{$\mathrm{MCV}$} & MCV-498-F & AGGATTATATGCAAAGTGGATATAATGCT & 84 & \\
\hline & MCV-527-R & CGCACTTAGAATCTCTAAGTTGCTTAA & & \\
\hline & MCV-525-Prb & HEX-TTTGCAGAGGTCCTGGGTGCATG-BHQ1 & & \\
\hline & LT3-F & TTGTCTCGCCAGCATTGTAG & 309 & Feng et al. [22] \\
\hline & LT3-R & ATATAGGGGCCTCGTCAACC & & \\
\hline & VP1-F & TTTGCCAGCTTACAGTGTGG & 352 & \\
\hline & VP1-R & TGGATCTAGGCCCTGATTTTT & & \\
\hline \multirow[t]{3}{*}{ HSV-1 } & HSV1UP & CGGCCGTGTGACACTATCG & 70 & Weidmann et al. [45] \\
\hline & HSV1DP & CTCGTAAAATGGCCCCTCC & & \\
\hline & HSV1P & HEX-CCATACCGACCACACCGACGAACC-BHQ1 & & \\
\hline \multirow[t]{3}{*}{ HSV-2 } & Watz-HSV2-F & CGCCAAATACGCCTTAGCA & 70 & Watzinger et al. [43] \\
\hline & Watz-HSV2-R & GAAGGTTCTTCCCGCGAAAT & & \\
\hline & Watz-HSV2-TM & FAM-CTCGCTTAAGATGGCCGATCCCAATC-BHQ1 & & \\
\hline
\end{tabular}

$\mathrm{W}=\mathrm{A}, \mathrm{T} ; \mathrm{I}=\mathrm{A}, \mathrm{T} \mathrm{G} \mathrm{C} ; \mathrm{Y}=\mathrm{C}, \mathrm{T} ; \mathrm{V}=\mathrm{A}, \mathrm{C}, \mathrm{G} ; \mathrm{H}=\mathrm{A}, \mathrm{C}, \mathrm{T} ; \mathrm{N}=\mathrm{A}, \mathrm{T}, \mathrm{G}, \mathrm{C} ; \mathrm{R}=\mathrm{A}, \mathrm{G} ; \mathrm{K}=\mathrm{G}, \mathrm{T} ; \mathrm{M}=\mathrm{A}, \mathrm{C}$ 
$60 \mathrm{~s}, 45^{\circ} \mathrm{C}$ for $60 \mathrm{~s}$, and $72^{\circ} \mathrm{C}$ for $60 \mathrm{~s}$. Of the original 27 endometriotic lesion samples, two were not positive for human L1 PCR and were therefore not included in this study.

The degenerate FAP primer pair detects a broad spectrum of HPV types by PCR [23]. The $25-\mu \mathrm{L}$ reaction mixtures contained $1 \times$ GeneAmp PCR Buffer II (Roche, Basel, Switzerland), $3.5 \mathrm{mM} \mathrm{MgCl} 2$ (Roche), $0.2 \%$ BSA (NEB), $0.2 \mathrm{mM}$ of each dNTP (Roche), $0.75 \mu \mathrm{M}$ of each of the primers FAP59 and FAP64, 0.625 U AmpliTaq Gold Polymerase (Roche), and $5 \mu \mathrm{L}$ clinical sample or control. Both undiluted and ten-fold-diluted samples were tested to ensure that the PCR was not inhibited by template overload. The PCR was incubated at $94^{\circ} \mathrm{C}$ for $10 \mathrm{~min}$, followed by 40 amplification cycles of $94^{\circ} \mathrm{C}$ for $90 \mathrm{~s}, 50^{\circ} \mathrm{C}$ for $90 \mathrm{~s}$, and $72^{\circ} \mathrm{C}$ for $90 \mathrm{~s}$.

The GP+ primer pair is designed for detecting a wide range of mucosal HPV types by PCR [16]. The $25-\mu \mathrm{L}$ reaction mixtures contained $1 \times$ Standard Taq Reaction Buffer with $1.5 \mathrm{mM} \mathrm{MgCl} 2$ (NEB), additional $\mathrm{MgCl}_{2}$ (Fermentas, Burlington, Ontario, Canada) to a final concentration of 3.5, $0.2 \mathrm{mM}$ of each dNTP (Fisher), $1 \mu \mathrm{M}$ of each of the GP5+ and GP6+ primers, $1 \mathrm{U}$ Taq DNA polymerase (NEB), and $5 \mu \mathrm{L}$ sample. The PCR was initially denatured at $94^{\circ} \mathrm{C}$ for $4 \mathrm{~min}$, followed by 40 amplification cycles of $94^{\circ} \mathrm{C}$ for $60 \mathrm{~s}, 40^{\circ} \mathrm{C}$ for $120 \mathrm{~s}$, and $72^{\circ} \mathrm{C}$ for $90 \mathrm{~s}$. A final extension step of $72^{\circ} \mathrm{C}$ for $4 \mathrm{~min}$ was included to ensure complete extension. A plasmid containing the entire HPV-18 genome was used as a positive control for both the FAP and the GP+ PCRs.

A multiplex PCR was used for simultaneous detection of the herpes virus family members HSV-1, HSV-2, CMV, and EBV. The $25-\mu \mathrm{L}$ mixtures contained $5 \mu \mathrm{L}$ template, $1 \times$ Standard Taq Reaction Buffer containing $1.5 \mathrm{mM}$ $\mathrm{MgCl}_{2}$ (NEB), $0.1 \mathrm{mM}$ of each dNTP (Fisher), $1.25 \mathrm{U}$ Taq DNA polymerase (NEB), and $0.5 \mu \mathrm{M}$ of each of the primers HSV-GF, HSV-1-2R, EBV-R, and CMV-R [38]. The template DNA was initially denatured at $94^{\circ} \mathrm{C}$ for $2 \mathrm{~min}$. After this cycle, 39 thermocycles of $94^{\circ} \mathrm{C}$ for $30 \mathrm{~s}$, $60^{\circ} \mathrm{C}$ for $45 \mathrm{~s}$, and $72^{\circ} \mathrm{C}$ for $45 \mathrm{~s}$ were performed. The reaction mixtures were further incubated at $72^{\circ} \mathrm{C}$ for $10 \mathrm{~min}$. For positive controls, DNA extracts of human tissue samples or cultured cell lines positive for HSV-1, HSV-2, and CMV were used. DNA was extracted as described above from EBV-positive cultured cells kindly donated by Dr. Viviana Lutzky and Prof. Denis Moss from Queensland Institute of Medical Research, Brisbane, QLD, Australia.

For detection of the polyomaviruses JC, BK, and SV40, a nested multiplex PCR was used. For the first amplification, the $25-\mu \mathrm{L}$ PCR mixtures contained $1 \times$ Standard Taq Reaction Buffer with $1.5 \mathrm{mM} \mathrm{MgCl}_{2}$ (NEB), additional
$\mathrm{MgCl}_{2}$ (Fermentas) to a final concentration of $2.0,0.2 \mathrm{mM}$ of each dNTP (Fisher), $1.25 \mathrm{U}$ Taq DNA polymerase (NEB), $5 \mu \mathrm{L}$ sample, and $0.4 \mu \mathrm{M}$ of each of the primers PM1+ and PM1- [21]. The PCR was initially denatured at $94^{\circ} \mathrm{C}$ for $2 \mathrm{~min}$, followed by 40 thermocycles of $94^{\circ} \mathrm{C}$ for $30 \mathrm{~s}, 61^{\circ} \mathrm{C}$ for $60 \mathrm{~s}$, and $72^{\circ} \mathrm{C}$ for $45 \mathrm{~s}$. A final extension step of $72^{\circ} \mathrm{C}$ for $5 \mathrm{~min}$ was conducted. For the nested amplification, the same reaction conditions were used except using only $1.5 \mathrm{mM} \mathrm{MgCl}{ }_{2}$ and $1 \mu \mathrm{L}$ of the first amplification PCR as template. Also, $0.4 \mu \mathrm{M}$ of the forward primers $\mathrm{BK}+, \mathrm{JC}+, \mathrm{SV}+$, and $0.5 \mu \mathrm{M}$ of the reverse PM2- primer were used [21]. The nested PCR was initially denatured at $94^{\circ} \mathrm{C}$ for $2 \mathrm{~min}$, followed by 30 thermocycles of $94^{\circ} \mathrm{C}$ for $30 \mathrm{~s}, 56^{\circ} \mathrm{C}$ for $60 \mathrm{~s}$, and $72^{\circ} \mathrm{C}$ for $30 \mathrm{~s}$ and a final extension step of $72^{\circ} \mathrm{C}$ for $5 \mathrm{~min}$. For positive controls, DNA extracts of human tissue samples or cultured cell lines positive for BKV and JCV were used, and DNA was extracted as described above from the SV40infected COS-1 cultured cell line (ATCC, Manassas, VA, USA).

Sterile distilled $\mathrm{H}_{2} \mathrm{O}$ was used as a negative control template for all reactions, and PCR master mixes were made in a strictly DNA-free environment to avoid contamination. Templates were added in a separate sterile environment, and all PCRs were carried out using a Thermo Hybaid $\mathrm{P} \times \mathrm{E}$ PCR machine. All PCR products were analyzed using agarose gel electrophoresis made with $1 \times$ TAE buffer (Amresco, Solon, OH, USA) and stained with $10 \mu \mathrm{g} / \mathrm{mL}$ ethidium bromide (Sigma-Aldrich, St. Louis, MO, USA). $1.5 \%$ agarose (Bioline, Alexandria, NSW, Australia) was used for standard PCR products and $2 \%$ for multiplex PCR products. The bands were visualized under UV light and photographed using GelDoc software (Bio-Rad, Hercules, CA, USA).

WUV and KIV were detected using previously published real-time PCR (rtPCR) assays (WU-B \& C, and KI-A \& B, respectively) [10]. MCV was also detected by rtPCR, and positive results were confirmed by the previously described LT3 and VP1 assays [22] and visualized by UV electrophoresis. Supplementary HSV-1 and -2 testing was performed using a duplex of previously published rtPCR assays for HSV-1 [45] and HSV-2 [43]. All rtPCR assays used a common PCR mix and protocol. Briefly, the rtPCR consisting of $12.5 \mu \mathrm{l}$ Quantitect Probe PCR Mix (Qiagen), 10 pmol of each primer, 4 pmol of each probe and $2 \mu \mathrm{l}$ of template in a $25-\mu \mathrm{l}$ final reaction was performed in either a Rotorgene 6000 (Qiagen) or a LightCycler 480 (Roche) under the following conditions: a 15 -minute incubation at $95^{\circ} \mathrm{C}$, followed by 45 cycles of $95^{\circ} \mathrm{C}$ for $15 \mathrm{~s}$ and $60^{\circ} \mathrm{C}$ for $60 \mathrm{~s}$. Clinical extracts were used as positive controls for the WUV, KIV, HSV-1 and HSV-2 assays, while synthetic oligonucleotides were used as the controls for the MCV assays. 
Cloning and sequencing

Upon positive HPV detection, FAP and GP+ PCR products were sequenced with one or both of the amplifying primers by the Australian Genome Research Facility Ltd (AGRF, Brisbane, QLD, Australia). If nonspecific background bands were present, the correctly sized bands were excised from the agarose gels, and the DNA was purified using a GelElute Extraction Kit (5 Prime, Gaithersburg, $\mathrm{MD}$, USA) prior to sequencing. If sequences were still ambiguous, the PCR products were cloned into the pCR2.1-TOPO vector using a TOPO TA Cloning Kit (Invitrogen, Carlsbad, CA, USA) according to the manufacturer's protocol. Bacterial colonies from LB plates supplemented with ampicillin $(1.5 \%$ LB plates with $50 \mu \mathrm{g} / \mathrm{mL}$ ampicillin) were picked and boiled at $99^{\circ} \mathrm{C}$ for $10 \mathrm{~min}$ and used as templates for check-insert PCR. PCR mixtures $(25 \mu \mathrm{L})$ were mixed as for the human L1 PCR, except that each of the M13 forward and reverse primers that flank the cloning site of the vector were used at a concentration of $1 \mu \mathrm{M}$. The PCRs were incubated at $94^{\circ} \mathrm{C}$ for $4 \mathrm{~min}$, followed by 35 amplification cycles of $94^{\circ} \mathrm{C}$ for $60 \mathrm{~s}, 45^{\circ} \mathrm{C}$ for $60 \mathrm{~s}$, and $72^{\circ} \mathrm{C}$ for $60 \mathrm{~s}$, and the products were analyzed by agarose gel electrophoresis and then sequenced. CLC Combined Workbench software (CLC Biotech, Aarhus, Denmark) was used for DNA sequence analysis, and BLAST analysis to identify HPV types.

\section{Statistical analysis}

Statistical analysis was performed using one-tailed Fisher's exact test, and a difference was considered significant if $P<0.05$.

\section{Results}

Clinical samples of eutopic endometrial tissue from control women without endometriosis $(\mathrm{C} ; n=20)$ and women with endometriosis ( $\mathrm{Eu} ; n=32$ ) were tested for the presence of a broad spectrum of DNA viruses. Samples of ectopic endometriotic lesions (Ec; $n=25)$ from the same endometriosis patients were also tested. All samples included in this study tested positive for human L1 DNA by PCR, confirming that they all contained DNA from human cells and that no PCR-inhibitory agents were present in the samples.

\section{Sensitivity of PCR assays}

The sensitivity of all non-real-time PCRs used in this study was previously shown to range from one to ten viral copies per $50 \mu \mathrm{L}[16,21,23,38]$, and all positive controls were successfully detected, except from HSV-1 and -2 . The limits of reliable detection for the HSV-1 and -2 rtPCR assays were 100 and 10 viral copies per reaction, respectively $[43,45]$. Both assays were capable of detecting their respective control samples, which suggests that unforeseen detrimental primer interactions or sequence variation may have impacted the sensitivity of the multiplex PCR HSV-1 and HSV-2 assays. The limit of detection in all WUV, KIV, and MCV rtPCR assays was 10 viral copies per reaction.

HPV prevalence in endometriosis and controls

HPV DNA was detected using the primer pairs FAP [23] and GP+ [16], both designed for amplifying fragments of the HPV L1 gene of DNA from a broad spectrum of HPV types.

Of the 32 endometriosis patients, only one Eu sample (3\%) tested positive for HPV DNA, and HPV was detected in the endometrium of two women from the $\mathrm{C}$ group (10\%) (Table 2). However, this difference in HPV DNA prevalence was not significantly different between the two study groups $(P=0.33)$. No HPV was found in the Ec group samples. There was no incidence of genital HPV infections, as investigated in cervical smears, in any of the patients or controls. The cervical smears were reanalyzed by the pathologist and did not show any sign of HPV infection correlating to the positive HPV PCR results.

The detected HPV types were sequenced directly from the PCR product or from subsequent cloning of the PCR product. HPV-70 and -90 were detected in the same sample by both PCR assays, whereas HPV-68 was detected only by the FAP PCR and HPV-35 only by the GP+ PCR. HPV-35, -68 and -70 are all high-risk for mucosal lesions, whereas HPV-90 is a low-risk mucosal type. All HPV types identified were mucosal genital HPV types belonging

Table 2 DNA viruses detected

\begin{tabular}{lllll}
\hline $\begin{array}{l}\text { Virus } \\
\text { family }\end{array}$ & $\begin{array}{l}\text { Tissue } \\
\text { group }\end{array}$ & $\begin{array}{l}\text { Virus } \\
\text { prevalence }\end{array}$ & Subjects & $\begin{array}{l}\text { Viruses } \\
\text { detected }\end{array}$ \\
\hline HPV & Ec & $0 / 25$ & & \\
& Eu & $1 / 32$ & 4 & HPV-68 \\
& $\mathrm{C}$ & $2 / 20$ & 10,21 & $\begin{array}{c}\text { HPV-70 and HPV-90, } \\
\text { HPV-35 }\end{array}$ \\
Herpes & Ec & $0 / 25$ & & \\
& Eu & $2 / 32$ & 8,16 & EBV, CMV \\
& $\mathrm{C}$ & $0 / 20$ & & \\
Polyoma & Ec & $0 / 25$ & & \\
& Eu & $0 / 32$ & & \\
& $\mathrm{C}$ & $1 / 20$ & 16 & MCV \\
\hline
\end{tabular}

$E c$ ectopic endometriosis lesions from women with endometriosis, $E u$ eutopic endometrium from women with endometriosis, $C$ endometrium from healthy control women 
to the genus Alphapapillomavirus [17]. There was no incidence of genital HPV infections in any of the patients or controls, or clinical correlation to the positive HPV PCR results.

Prevalence of members of the herpes virus family in endometriosis and controls

The prevalence of members of the herpes virus family was analyzed using a multiplex PCR designed to detect the presence of CMV, EBV, and HSV-1 and -2.

EBV and CMV were each found in one (3\%) of the Eu samples (Table 2), whereas the Ec and C samples all tested negative by this multiplex PCR. This difference between the $\mathrm{Eu}$ and $\mathrm{C}$ groups was not statistically significant $(P=0.62)$.

Where CMV and EBV were easily detected in both positive clinical and control samples, this multiplex PCR unfortunately failed to detect HSV-1 and -2 from four different control samples, and therefore, the prevalence of HSV-1 and -2 could not be determined using this method. The HSV-1 and -2 real-time PCR successfully detected the control samples, but supplementary testing with the assays did not identify any HSV-1 or -2 within any of the tissue samples.

Polyomavirus prevalence in endometriosis and controls

When testing the nested multiplex polyomavirus PCR on positive control samples, each of the viruses BKV, JCV, and SV40 were clearly detected, and all clinical samples were tested. No polyomaviruses were detected in the $\mathrm{Eu}$ and Ec samples. Similarly, no WUV or KIV was detected within either of the sample populations by rtPCR. MCV was detected in one $\mathrm{C}$ group sample (5\%), and this was subsequently confirmed with both the LT3 and VP1 assays (Table 2). The difference in prevalence to the Eu and Ec groups with no identified MCV was not statistically significant $(P=0.39)$.

\section{Discussion}

The malignant and immunological processes in endometriosis could indicate the existence of a possible causal infectious agent. This study has focused on investigating the presence of the most common pathogenic DNA viruses in the endometrium and endometriotic lesions from women with endometriosis versus healthy women.

The prevalence of HPV in the tissue samples was determined by combined FAP and GP+ PCR analyses. The prevalence of HPV in the endometrium of the Eu and $\mathrm{C}$ groups was low and not significantly different between the groups $(P=0.33)$. No HPV DNA was found in the endometriotic lesions of the Ec group. All HPV types detected in the endometrial tissues were genital types of the alpha-papillomavirus genus, and both high- and low-risk types were identified. The degenerate FAP and GP+ primer pairs both detected HPV types that were not detected by the other primer set, albeit with some overlap between the two PCR assays. This demonstrates that the FAP and GP+ PCRs are good complementary assays for detection of HPV in this type of sample.

Only one previous publication has addressed the prevalence of HPV in the endometrium as well as in endometriosis. Oppelt et al. [35] have studied 56 German endometriosis patients, out of which nine $(16.1 \%)$ had been diagnosed with cervical intraepithelial neoplasia (CIN) or cervical, ovarian, or endometrial carcinoma. Sixty-six endometriosis lesions from these women were studied, of which 59 were classified as AFS stage 1-4, while seven had no available AFS classification. The authors also studied 13 women without endometriosis, of which 11 (81.8\%) had CIN or cervical carcinoma. The control group consisted of 30 non-endometriosis tissue samples, both from endometriosis patients and from these non-endometriosis subjects with a clinical bias for a previous HPV infection.

Oppelt et al. [35] amplified the HPV L1 gene by PCR, and the amplicons were detected by an ELISA method using hybridization with probes that were specific for either low-risk or high-risk HPV types. HPV-positive tissues were also tested using the Invader 2.0 HPV High-Risk Molecular Assay, which recognizes only the high-risk HPV types. HPV DNA was identified in seven $(11.3 \%)$ of 62 interpretable endometriosis lesions as well as in eight $(27.5 \%)$ of 29 control tissues. This is not surprising when considering the high frequencies of CIN and genital carcinomas of these groups.

The sensitivity of the PCR-ELISA method used by Oppelt et al. was $1.0 \mathrm{pg}$, corresponding to approximately 80,000 copies of the viral genome, whereas the FAP and $\mathrm{GP}+$ primer sets used in this study can detect less than ten viral copies $[16,23]$. As the primer sequences used in the PCR-ELISA were not noted, it is difficult to evaluate their specificity, and the Invader method was less sensitive than the PCR-ELISA method.

From the study by Oppelt et al., it was concluded that certain high-risk HPV types can be found in endometriosis lesions. However, as cervical intraepithelial neoplasias and malignant carcinomas are well-known to frequently be caused by HPV [42], the detected HPV types could originate from these associated malignant transformations and might not have any association with the diagnosis of endometriosis. Furthermore, as the control group was biased, no conclusions of a possible endometriosis-associated change in HPV 
prevalence can be made from the Oppelt et al. study. Thus, their findings cannot be compared directly with the low HPV prevalence found in this study.

In another small clinical study, expression of human endogenous retroviruses in endometriotic tissues was detected, indicating that endogenous retrovirus expression might be involved in endometriosis [28], but further investigations are needed to determine the significance of these results.

All clinical samples were tested by multiplex PCR for the presence of the herpes viruses CMV and EBV. The Ec lesions and the endometrial samples of the $\mathrm{C}$ group were all negative for these herpes viruses, whereas a low prevalence of CMV and EBV was detected in the Eu group of endometrial samples. The multiplex PCR failed to detect positive HSV-1 and -2 control samples, but a supplementary real-time PCR method successfully detected these positive controls. None of the clinical samples were positive for either HSV-1 or -2 .

Finally, a nested multiplex PCR was used to test all clinical samples for the presence of the polyomaviruses $\mathrm{JCV}, \mathrm{BKV}$, and SV40, and rtPCR assays were used for detection of WUV, KIV, and MCV. One C group sample was positive for MCV, but no other polyomaviruses were detected, suggesting an infrequent presence of polyomaviruses in the endometrium.

The determined prevalence of DNA viruses in the endometrium of $0-10 \%$ is remarkably low compared with the well-known high frequencies of infection with the majority of these viruses. It is estimated that $75-80 \%$ of sexually active individuals are infected with HPV during their lifetime, with the highest rates in women younger than 25 years of age [44]. However, as the mean age of the enrolled women was between 32 and 36 years of age, most HPV infections would have been cleared by the immune system [6]. This correlates well with the fact that no patients showed genital HPV infection in cervical smears. The incidence of the recently discovered WUV, KIV, and $\mathrm{MCV}$ remains to be elucidated, but the seroprevalence of all other viruses tested for in this study lies within the range of $15-95 \%$ [27, 33].

It can be speculated that the endometrium and endometriotic tissue are an unfavorable environment for virus progression, leading to a generally low prevalence in these deeper tissues. It is possible that viruses infect the endometrium transiently but are subsequently either shed with the endometrial tissue during menstruation or are rapidly cleared by an efficient immune response. In this way, stable infections of the endometrium would not be frequent. However, a pathogenic virus could theoretically initiate a malignant cell process during a shorter infectious period and then flee the scene. This "hit-and-run" strategy has been shown previously for CMV in vitro $[14,24]$ and indicated in clinical studies of both polyomaviruses and papillomaviruses $[4,5,8,29]$. This could explain that no virus DNA was found in the lesions. To address this hypothesis, it would be interesting to test for elevated presence of serum antibodies against the viruses, which would also show previous viral infections.

To further investigate the hypothesis of an infectious agent as the cause of endometriosis, it would be interesting to perform epidemiological studies on the incidence of endometriosis compared with the use of immunosuppressive drugs, e.g. in transplant patients. A correlating elevated incidence would indicate a causal infectious agent. A broad selection of the most common pathogenic DNA viruses has been tested for in this study, but other viruses or bacteria not yet tested for could be involved.

In conclusion, the prevalence of pathogenic DNA viruses in the endometrium and endometriosis lesions is very low and does not indicate a virological cause of endometriosis. However, the existence of an infectious causal agent cannot be ruled out at this point. Further investigations are needed, and the search for the aetiology of endometriosis continues.

Acknowledgments We would like to thank Dr. Viviana Lutzky and Prof. Denis Moss from Queensland Institute of Medical Research, Brisbane, QLD, Australia, for donating positive control virus samples. Thanks are also due to Dr. Nigel McMillan for stimulating discussions. This work was supported by the Novo Nordisk Foundation, A. P. Møller's Foundation for the Advancement of Medical Science, Aarhus Graduate School of Science, the Augustinus Foundation, the Harboe Foundation, Familien Hede Nielsen's Foundation, Knud Højgaard's Foundation, the Oticon Foundation, and Ingeniør Alexandre Haynman og hustru Nina Haynman's Foundation, Denmark, Svenska Sällskapet för Medicinsk Forskning and the Mazda foundation, Sweden, and the Prostate Cancer Foundation, Australia.

\section{References}

1. Acien P, Quereda F, Campos A, Gomez-Torres MJ, Velasco I, Gutierrez M (2002) Use of intraperitoneal interferon alpha-2b therapy after conservative surgery for endometriosis and postoperative medical treatment with depot gonadotropin-releasing hormone analog: a randomized clinical trial. Fertil Steril 78:705711

2. Ali AFM, Fateen B, Ezzet A, Badawy H, Ramadan A, El-tobge A (2000) Laparoscopic intraperitoneal injection of human interferon-[alpha] $2 b$ in the treatment of pelvic endometriosis: a new modality. Obstet Gynecol 95:S47-S48

3. Allander T, Andreasson K, Gupta S, Bjerkner A, Bogdanovic G, Persson MAA, Dalianis T, Ramqvist T, Andersson B (2007) Identification of a third human polyomavirus. J Virol 81:4130 4136

4. Anderson RA, Scobie L, O'Neil BW, Grindlay GJ, Campo MS (1997) Viral proteins of bovine papillomavirus type 4 during the development of alimentary canal tumours. Vet J 154:69-78

5. Aubin F, Humbey O, Guerrini JS, Mougin C, Laurent R (2003) Non-melanoma skin cancers and human papillomavirus. Ann Dermatol Venereol 130:1131-1138 
6. Ault KA (2006) Epidemiology and natural history of human papillomavirus infections in the female genital tract. Infect Dis Obstet Gynecol 2006(Suppl):40470

7. Badawy SZA, Etman A, Cuenca V, Montante A, Kaufman L (2001) Effect of interferon alpha-2b on endometrioma cells in vitro. Obstet Gynecol 98:417-420

8. Barbanti-Brodano G, Sabbioni S, Martini F, Negrini M, Corallini A, Tognon M (2004) Simian virus 40 infection in humans and association with human diseases: results and hypotheses. Virology 318:1-9

9. Béliard A, Noël A, Foidart J-M (2004) Reduction of apoptosis and proliferation in endometriosis. Fertil Steril 82:80-85

10. Bialasiewicz S, Whiley DM, Lambert SB, Gould A, Nissen MD, Sloots TP (2007) Development and evaluation of real-time PCR assays for the detection of the newly identified KI and WU polyomaviruses. J Clin Virol 40:9-14

11. Brown HL, Abernathy MP (1998) Cytomegalovirus infection. Semin Perinatol 22:260-266

12. Caldarelli-Stefano R, Vago L, Omodeo-Zorini E, Mediati M, Losciale L, Nebuloni M, Costanzi G, Ferrante P (1999) Detection and typing of JC virus in autopsy brains and extraneural organs of AIDS patients and non-immunocompromised individuals. J Neurovirol 5:125-133

13. Chen AC, Keleher A, Kedda MA, Spurdle AB, McMillan NA, Antonsson A (2009) Human papillomavirus DNA detected in peripheral blood samples from healthy Australian male blood donors. J Med Virol 81:1792-1796

14. Cinatl J Jr, Cinatl J, Vogel JU, Rabenau H, Kornhuber B, Doerr HW (1996) Modulatory effects of human cytomegalovirus infection on malignant properties of cancer cells. Intervirology 39:259-269

15. Comar M, Rizzardi C, de Zotti R, Melato M, Bovenzi M, Butel JS, Campello C (2007) SV40 multiple tissue infection and asbestos exposure in a hyperendemic area for malignant mesothelioma. Cancer Res 67:8456-8459

16. de Roda Husman A-M, Walboomers JMM, van den Brule AJC, Meijer CJLM, Snijders PJF (1995) The use of general primers GP5 and GP6 elongated at their $3^{\prime}$ ends with adjacent highly conserved sequences improves human papillomavirus detection by PCR. J Gen Virol 76:1057-1062

17. de Villiers EM, Fauquet C, Broker TR, Bernard HU, zur Hausen H (2004) Classification of papillomaviruses. Virology 324:17-27

18. Deragon JM, Sinnett D, Mitchell G, Potier M, Labuda D (1990) Use of gamma irradiation to eliminate DNA contamination for PCR. Nucleic Acids Res 18:6149

19. Dolcetti R, Masucci MG (2003) Epstein-Barr virus: induction and control of cell transformation. J Cell Physiol 196:207-218

20. Dörries K (2002) Latent and persistent polyomavirus infection. In: Kamel Khalili GLS (ed) Human polyomaviruses. Wiley-Liss, Inc., Wilmington, pp 197-235

21. Fedele CG, Ciardi M, Delia S, Echevarria JM, Tenorio A (1999) Multiplex polymerase chain reaction for the simultaneous detection and typing of polyomavirus JC, BK and SV40 DNA in clinical samples. J Virol Methods 82:137-144

22. Feng H, Shuda M, Chang Y, Moore PS (2008) Clonal integration of a polyomavirus in human Merkel cell carcinoma. Science 319:1096-1100

23. Forslund O, Antonsson A, Nordin P, Stenquist B, Goran Hansson B (1999) A broad range of human papillomavirus types detected with a general PCR method suitable for analysis of cutaneous tumours and normal skin. J Gen Virol 80:2437-2443

24. Galloway DA, McDougall JK (1983) The oncogenic potential of herpes simplex viruses: evidence for a 'hit-and-run' mechanism. Nature 302:21-24

25. Gaynor AM, Nissen MD, Whiley DM, Mackay IM, Lambert SB, Wu G, Brennan DC, Storch GA, Sloots TP, Wang D (2007)
Identification of a novel polyomavirus from patients with acute respiratory tract infections. PLoS Pathog 3:e64

26. Giudice LC, Kao LC (2004) Endometriosis. Lancet 364:1789_ 1799

27. Gupta R, Warren T, Wald A (2007) Genital herpes. Lancet 370:2127-2137

28. Hu L, Hornung D, Kurek R, Ostman H, Blomberg J, Bergqvist A (2006) Expression of human endogenous gammaretroviral sequences in endometriosis and ovarian cancer. AIDS Res Hum Retroviruses 22:551-557

29. Khalili K, Del Valle L, Otte J, Weaver M, Gordon J (2003) Human neurotropic polyomavirus, JCV, and its role in carcinogenesis. Oncogene 22:5181-5191

30. Kutsuna T, Zheng H, Abdel-Aziz HO, Murai Y, Tsuneyama K, Furuta I, Takano Y (2008) High JC virus load in tongue carcinomas may be a risk factor for tongue tumorigenesis. Virchows Arch 452:405-410

31. Lefrancq T, Orain I, Michalak S, Hourseau M, Fetissof F (1999) Herpetic salpingitis and fallopian tube prolapse. Histopathology 34:548-550

32. Melin A, Sparen P, Bergqvist A (2007) The risk of cancer and the role of parity among women with endometriosis. Hum Reprod 22:3021-3026

33. Moens U, Johannessen M (2008) Human polyomaviruses and cancer: expanding repertoire. J Dtsch Dermatol Ges 6:704-708

34. Neske F, Blessing K, Pröttel A, Ullrich F, Kreth HW, Weissbrich B (2009) Detection of WU polyomavirus DNA by real-time PCR in nasopharyngeal aspirates, serum, and stool samples. J Clin Virol 44:115-118

35. Oppelt P, Renner SP, Strick R, Valletta D, Mehlhorn G, Fasching PA, Beckmann MW, Strissel PL (2009) Correlation of high-risk human papilloma viruses but not of herpes viruses or Chlamydia trachomatis with endometriosis lesions. Fertil Steril (in press)

36. Pietropaolo V, Fioriti D, Simeone P, Videtta M, Di Taranto C, Arancio A, Orsi N, Degener AM (2003) Detection and sequence analysis of human polyomaviruses DNA from autoptic samples of HIV-1 positive and negative subjects. Int J Immunopathol Pharmacol 16:269-276

37. Paavonen J, Teisala K, Heinonen PK, Aine R, Miettinen A, Lehtinen M, Gronroos P (1985) Endometritis and acute salpingitis associated with Chlamydia trachomatis and herpes simplex virus type two. Obstet Gynecol 65:288-291

38. Sahin F, Gerceker D, Karasartova D, Ozsan TM (2007) Detection of herpes simplex virus type 1 in addition to Epstein-Bar virus in tonsils using a new multiplex polymerase chain reaction assay. Diagn Microbiol Infect Dis 57:47-51

39. Sharp Colin ÂP, Norja Pi, Anthony I, Bell Jeanne ÂE, Simmonds P (2009) Reactivation and mutation of newly discovered WU, KI, and Merkel cell carcinoma polyomaviruses in immunosuppressed individuals. J Infect Dis 199:398-404

40. Sinaii N, Cleary SD, Ballweg ML, Nieman LK, Stratton P (2002) High rates of autoimmune and endocrine disorders, fibromyalgia, chronic fatigue syndrome and atopic diseases among women with endometriosis: a survey analysis. Hum Reprod 17:2715-2724

41. Siristatidis C, Nissotakis C, Chrelias C, Iacovidou H, Salamalekis E (2006) Immunological factors and their role in the genesis and development of endometriosis. J Obstet Gynaecol Res 32:162170

42. Walboomers JMM, Jacobs MV, Manos MM, Bosch FX, Kummer JA, Shah KV, Snijders PJ, Peto J, Meijer CJ, Muñoz N (1999) Human papillomavirus is a necessary cause of invasive cervical cancer worldwide. J Pathol 189:12-19

43. Watzinger F, Suda M, Preuner S, Baumgartinger R, Ebner K, Baskova L, Niesters HGM, Lawitschka A, Lion T (2004) Realtime quantitative PCR assays for detection and monitoring of 
pathogenic human viruses in immunosuppressed pediatric patients. J Clin Microbiol 42:5189-5198

44. Weaver BA (2006) Epidemiology and natural history of genital human papillomavirus infection. J Am Osteopathic Assoc 106:S2-S8

45. Weidmann M, Meyer-Konig U, Hufert FT (2003) Rapid detection of herpes simplex virus and varicella-zoster virus infections by real-time PCR. J Clin Microbiol 41:1565-1568
46. Wilson SS, Fakioglu E, Herold BC (2009) Novel approaches in fighting herpes simplex virus infections. Expert Rev Anti Infect Ther 7:559-568

47. zur Hausen H (2009) Papillomaviruses in the causation of human cancers - a brief historical account. Virology 384:260-265 